\title{
Transition from Oral Selexipag to Subcutaneous Treprostinil in a Patient with Idiopathic Pulmonary Arterial Hypertension: An Eight-Day Protocol
}

\author{
İdiopatik Pulmoner Hipertansiyonlu Bir Hastada Oral Selexipag'den Subkutan \\ Treprostinil'e Geçiş: Sekiz Günlük Bir Protokol
}

Wan-Jing Ho, Chia-Pin Lin, Lung-An Hsu, Chun-Li Wang

\begin{abstract}
Pulmonary arterial hypertension (PAH) is a progressive and debilitating disorder. Specific medications target the nitric oxide, endothelin and prostacyclin pathways. Oral medications are usually administered in low-risk patients, while parenteral prostanoids are recommended for those at high risk, especially those with a WHO functional class of IV or those in whom the therapeutic goals of oral medications were not achieved. Selexipag is a selective prostacyclin (PGI2) receptor (IP receptor) agonist, while Treprostinil is a prostacyclin analog. There are no standard guidelines directing the transition from oral selexipag to subcutaneous (SC) treprostinil. We describe here a successful approach to this transition in a patient with idiopathic $\mathrm{PAH}$, proposing an 8-day protocol that may serve as a useful guide in clinical practice. The estimated equivalent doses of oral selexipag to SC treprostinil is $200 \mu \mathrm{g}$ twice daily $=5 \mathrm{ng} / \mathrm{kg} / \mathrm{min}$. Following the transition, the patient experienced improvements in symptoms, serum B-type natriuretic peptide levels, oxygen saturation and echocardiographic parameters.
\end{abstract}

Key words: Pulmonary arterial hypertension, selexipag, treprostinil.

\section{Özet}

Pulmoner arteriyel hipertansiyon (PAH) ilerleyici ve güçten düşürücü bir hastalıktır. Spesifik ilaçlar, nitrik oksit, endotelin ve prostasiklin yollarını hedeflemektedir. Oral ilaçlar genellikle düşük riskli hastalarda uygulanırken, yüksek riskli hastalarda, özellikle WHO fonksiyonel sınıf IV olanlarda veya oral ilaçların terapötik hedeflerine ulaşamayanlarda, parenteral prostanoidler önerilmektedir. Selexipag, selektif bir prostasiklin (PGI2) reseptörü agonistidir. Treprostinil bir prostasiklin analoğudur. Oral seleksipag'dan subku$\tan (\mathrm{SC})$ treprostinile geçiş için standart bir kılavuz yoktur. İdiyopatik PAH'lı bir hastada bu geçişe başarılı bir yaklaşım tanımladık. Klinik uygulamada faydalı bir rehber olabilecek 8 günlük bir protokol sunuyoruz. Oral seleksipag'ın SC treprostinile tahmini eşdeğer dozları günde iki kez $200 \mu \mathrm{g}=5 \mathrm{ng} / \mathrm{kg} / \mathrm{dk}$ 'dır. Geçişten sonra semptomlarda, serum $B$ tipi natriüretik peptit seviyelerinde, oksijen satürasyonunda ve ekokardiyografik parametrelerde iyileşmeler oldu.

Anahtar Sözcükler: Ppulmoner arterial hipertansiyon, selexipag, treprostinil.

Department of Cardiology, Chang Gung Memorial Hospital,

Chang Gung Universitesi, Tıp Fakültesi, Chan Gung

College of Medicine, Chang Gung University, Taoyuan, Taiwan

Memorial Hastanesi, Kardiyoloji Servisi, Taoyuan, Tayvan

Submitted (Başvuru tarihi): 04.06.2021 Accepted (Kabul tarihi): 25.08.2021

Correspondence (iletişim): Wan-Jing Ho, Department of Cardiology, Chang Gung Memorial Hospital, College of Medicine, Chang Gung University, Taoyuan, Taiwan

e-mail: auditory@cgmh.org.tw 
Despite the advances in pulmonary arterial hypertension (PAH)-specific drugs, PAH continues to be a progressive and debilitating disorder (1). Contemporary medications target the nitric oxide (NO), endothelin (ET) and prostacyclin pathways. Oral medications are administered usually in low-risk patients, while parenteral prostanoids are recommended for those at high risk, especially those with World Health Organization (WHO) functional class IV or those in whom the therapeutic goals of oral medications were not achieved $(2,3)$. There are no accepted guidelines directing the transition from oral selexipag to subcutaneous (SC) treprostinil. We describe here a successful approach to such a transition in a patient with idiopathic $\mathrm{PAH}$.

\section{CASE}

A 39-year-old, 50-kg woman who was diagnosed with idiopathic PAH in 2012, and who was on triple combination oral PAH-specific medications of sildenafil $20 \mathrm{mg}$ three times daily, macitentan $10 \mathrm{mg}$ once daily and selexipag $1600 \mu \mathrm{g}$ twice daily (BID), experienced disease progression to functional class III. Her 6-min walk distance was $410 \mathrm{~m}$. She was admitted to hospital for transition from oral selexipag to SC treprostinil. A right-heart catheterization was performed one week prior to the transitional therapy, when her hemodynamics were as follows: mean right atrial pressure, $18 \mathrm{mmHg}$; pulmonary artery pressure, $127 / 49 \mathrm{mmHg}$ (mean $73 \mathrm{mmHg}$ ); pulmonary artery wedge pressure, $14 \mathrm{mmHg}$; cardiac output, 3.9 $\mathrm{L} / \mathrm{min}$; cardiac index, $2.6 \mathrm{~L} / \mathrm{min} / \mathrm{m}^{2}$; pulmonary vascular resistance, 15 Wood units; and mixed venous oxygen saturation, $56 \%$. Her biochemical data on the day of admission were as follows: serum creatinine, $0.87 \mathrm{mg} / \mathrm{dL}$; blood urea nitrogen, $17.3 \mathrm{mg} / \mathrm{dL}$; alanine aminotransferase, 14 units/L; aspartate aminotransferase, 22 units/L; alkaline phosphatase, 67 units/L; total bilirubin, 1.1 $\mathrm{mg} / \mathrm{dL}$; and uric acid, $7.5 \mathrm{mg} / \mathrm{dL}$. The patient was categorized as high risk in a risk assessment of PAH following ERS/ESC guidelines $(3,4)$. She had been on the maximum dose of selexipag with the side effect of diarrhea, and our goal was to wean her from selexipag and gradually escalate treprostinil to a level of $40 \mathrm{ng} / \mathrm{kg} / \mathrm{min}$. The patient's informed consent for SC treprostinil treatment was obtained the start of transitional therapy. Given the differ- ence in the half-life of selexipag (6.2-13.5 h) and treprostinil $(2-4$ h) $(5,6)$, we developed a protocol to take into account the clinical worsening due to withdrawal of selexipag, and the side effects of the initiation and uptitrating of treprostinil. We decreased the dose of selexipag by $200 \mu \mathrm{g} \mathrm{BID}$ and increased the infusion dose of treprostinil by $5 \mathrm{ng} / \mathrm{kg} / \mathrm{min}$ every morning after assessing the patient's symptoms and evaluating the side effects of the prostanoid. Following this protocol, selexipag was weaned on the 8th day, and the dose of treprostinil was increased simultaneously to $40 \mathrm{ng} / \mathrm{kg} / \mathrm{min}$ (Table 1). We monitored the patient's vital signs and symptoms BID per routine and asked her to repeat her daily hall walk to detect any worsening of dyspnea on exertion. Serum Btype natriuretic peptide (BNP) levels were checked every three days, and electrocardiography (ECG), chest radiography and echocardiography were performed before the transition and after it was completed.

She was weaned from selexipag over 7 days, which was 1 day ahead of the schedule, and the treprostinil dose was increased to $40 \mathrm{ng} / \mathrm{kg} / \mathrm{min}$ upon discharge on day 8 of the transition (Figure 1). Table 1 shows the planned and actual "step-down" doses of selexipag and the "step-up" doses of treprostinil, as well as the vital signs, side effects and BNP levels throughout the 8-day transitional period. The patient experienced nausea, anorexia, flushing and fever on day 3 of the transition, leading us to reduce the dose of selexipag from $1200 \mu \mathrm{g}$ to $800 \mu \mathrm{g}$, rather than to the planned dose of $1000 \mu \mathrm{g}$. There were no doselimiting side effects such as hypotension, diarrhea, jaw pain or muscle pain after increasing the treprostinil dose. The most common side effect was SC infusion site pain in the right lower quadrant of the abdomen that started on day 4 following the puncture, peaked on day 5 and had almost subsided on day 8 . Ultracet (tramadol $37.5 \mathrm{mg}$ and acetaminophen $325 \mathrm{mg}$ ) was administered every $6 \mathrm{~h}$ for 3 days to control the pain. With the disappearance of nausea, her appetite returned on day 7 of the transition. She reported decreased dyspnea on exertion and chest tightness at rest on day 7. Selexipag was weaned on day 7. The serum BNP levels were $579 \mathrm{pg} / \mathrm{mL}$ before the transition and $572.5 \mathrm{pg} / \mathrm{mL}$ on day 4 , and reduced to $320.3 \mathrm{pg} / \mathrm{mL}$ on day 7 . 
Table 1: Doses of selexipag and treprostinil, vital signs, side-effects and BNP levels during the 8-day transitional therapy

\begin{tabular}{|c|c|c|c|c|c|c|c|c|c|c|}
\hline \multirow[t]{2}{*}{$\begin{array}{l}\text { Time } \\
\text { (day) }\end{array}$} & \multicolumn{2}{|c|}{ Selexipag $(\mu \mathrm{g})$} & \multicolumn{2}{|c|}{$\begin{array}{l}\text { Treprostinil } \\
\text { (ng/kg/min) }\end{array}$} & \multicolumn{4}{|c|}{ Vital signs* } & \multirow[t]{2}{*}{ Side-effects } & \multirow[t]{2}{*}{$\begin{array}{c}\text { BNP } \\
(\mathrm{pg} / \mathrm{mL})\end{array}$} \\
\hline & Planned & Actual & Planned & Actual & $\mathrm{BP}$ & PR & BT & RR & & \\
\hline 0 & 1600 & 1600 & 0 & 0 & $108 / 81$ & 104 & 36.2 & 17 & Nothing particular & 579.0 \\
\hline 1 & 1400 & 1400 & 5 & 5 & 107/75 & 89 & 36.3 & 15 & Nothing particular & \\
\hline 2 & 1200 & 1200 & 10 & 10 & $94 / 69$ & 87 & 36.2 & 16 & Mild nausea & \\
\hline 3 & 1000 & 800 & 15 & 15 & $113 / 84$ & 83 & 35.7 & 17 & Nausea, flushing, fever, anorexia & \\
\hline 4 & 800 & 600 & 20 & 20 & $112 / 69$ & 82 & 36.2 & 15 & Nausea, infusion site pain, & 572.5 \\
\hline 5 & 600 & 400 & 25 & 25 & $108 / 76$ & 102 & 37.0 & 15 & Flushing, nausea, severe infusion site pain & \\
\hline 6 & 400 & 200 & 30 & 30 & $140 / 79$ & 99 & 36.2 & 15 & Less flushing, nausea and infusion site pain & \\
\hline 7 & 200 & 0 & 35 & 35 & $107 / 72$ & 80 & 36.4 & 15 & Less infusion site pain, no nausea and anorexia & 320.3 \\
\hline 8 & 0 & 0 & 40 & 40 & $113 / 73$ & 87 & 36.8 & 15 & Mild infusion site pain & \\
\hline
\end{tabular}

*Vital signs included blood pressure $(B P, \mathrm{mmHg})$, pulse rate ( $P R$, beats per minute), body temperature $\left(B T,{ }^{\circ} \mathrm{C}\right)$ and respiratory rate ( $R R$, breaths per minute).

$B N P, B$-type natriuretic peptide.

Table 2: Echocardiographic findings before the transition and on day 7 of subcutaneous treprostinil administration

\begin{tabular}{|c|c|c|c|c|c|c|c|c|c|c|c|c|c|c|}
\hline $\begin{array}{l}\text { Time } \\
\text { (day) }\end{array}$ & $\begin{array}{l}\text { RVD } \\
(\mathrm{cm})\end{array}$ & $\begin{array}{l}\text { RAA } \\
\left(\mathrm{cm}^{2}\right)\end{array}$ & $\begin{array}{l}\text { RVFAC } \\
\text { (\%) }\end{array}$ & $\begin{array}{l}\text { TR } \\
\text { grade }\end{array}$ & $\begin{array}{l}\text { TRV } \\
(\mathrm{m} / \mathrm{s})\end{array}$ & $\begin{array}{l}\text { PR } \\
\text { grade }\end{array}$ & $\begin{array}{l}\text { PRV } \\
(\mathrm{m} / \mathrm{s})\end{array}$ & $\begin{array}{l}\text { IVC } \\
(\mathrm{cm})\end{array}$ & $\begin{array}{l}\text { SPAP* } \\
(\mathrm{mmHg})\end{array}$ & $\begin{array}{l}\text { TAPSE } \\
(\mathrm{cm})\end{array}$ & $\begin{array}{l}\text { LVel } \\
\mathrm{D} / \mathrm{S}\end{array}$ & $\begin{array}{l}\mathrm{SpO}_{2} \\
(\%)\end{array}$ & $\begin{array}{c}\text { Selexipag } \\
(\mu \mathrm{g})\end{array}$ & $\begin{array}{l}\text { Treprostinil } \\
\text { (ng/ } / \mathrm{kg} / \mathrm{min} \text { ) }\end{array}$ \\
\hline 0 & 4.1 & 33.1 & 13.6 & Mild & 5.2 & Mild & 4.1 & 2.2 & 124 & 1.1 & $2.6 / 5.5$ & 90 & 1600 & 0 \\
\hline 7 & 3.9 & 30.8 & 16.3 & Mild & 4.6 & Mild & 3.9 & 2.3 & 98 & 1.2 & $1.9 / 3.4$ & 93 & 0 & 35 \\
\hline
\end{tabular}

* Estimated systolic pulmonary artery pressure (SPAP) obtained by $4 \times T R V^{2}+R A$ pressure. The RA pressure was estimated by the diameter and inspiratory collapse of the inferior vena cava from the subcostal view.

IVC, maximal diameter of inferior vena cava; LVel D/S, left ventricular eccentricity index at diastole/systole; PR, pulmonary regurgitation; PRV, maximal velocity of pulmonary regurgitation; RAA, right atrial area; $R V D$, basal diameter of right ventricle; RVFAC, right ventricular fractional area change; $\mathrm{SpO}_{2}$, oxygen saturation by pulse oximeter; TAPSE; tricuspid annular plane systolic excursion; TR, tricuspid regurgitation;

TRV, peak tricuspid regurgitation jet velocity 


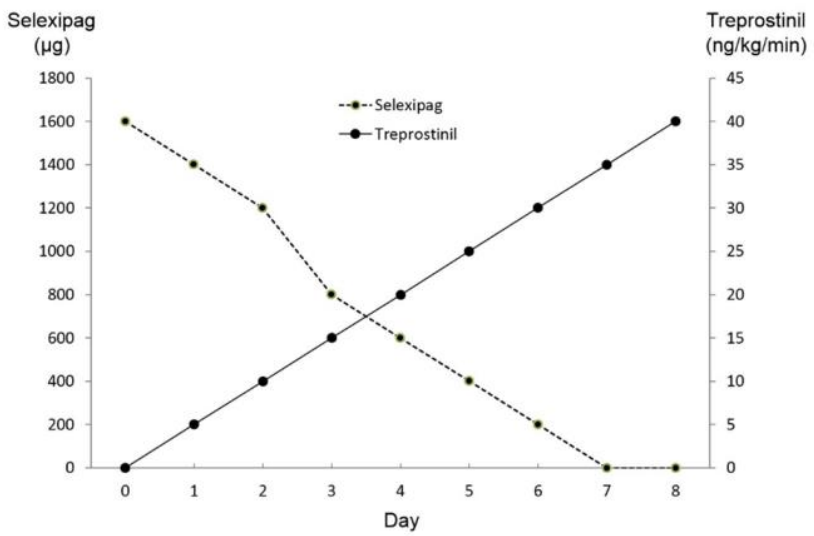

Figure 1: Eight-day transitional therapy from oral selexipag to subcutaneous treprostinil. The doses of selexipag were decreased by $200 \mu \mathrm{g}$ BID (except $400 \mu \mathrm{g}$ reduction on day 3 due to patient's complaint of flushing, nausea, and fever), while treprostinil dose was increased by 5 $\mathrm{ng} / \mathrm{kg} / \mathrm{min}$ daily

The chest radiography and ECG results remained constant during the transition. Table 2 shows the echocardiographic findings before the transition and on day 7 of SC treprostinil administration. The estimated systolic pulmonary artery pressure (SPAP), left ventricular eccentricity index (LVel), and the sizes of the right atrium and ventricle decreased after the transitional period, while the right ventricular fractional area change (RVFAC) and tricuspid annular plane systolic excursion (TAPSE) increased after SC treprostinil. Oxygen saturation measured by pulse oximeter in room air increased from $90 \%$ to $93 \%$. The patient was discharged on day 8 with a treprostinil dose of $40 \mathrm{ng} / \mathrm{kg} / \mathrm{min}$, and was asked to return to the clinic 1 week after the completion of the transition. Upon her return visit, she had no complaint of side effects other than mild diarrhea and reported improved exercise tolerance, palpitations and chest tightness.

\section{DISCUSSION}

Our patient transitioned successfully from oral selexipag to SC treprostinil with an 8-day transition protocol. The estimated equivalent dose of selexipag $200 \mu \mathrm{g}$ BID was converted to treprostinil $5 \mathrm{ng} / \mathrm{kg} / \mathrm{min}$. There were improvements in symptoms, serum BNP levels, oxygen saturation, and echocardiographic parameters after the transition.

Selexipag is an oral selective prostacyclin (PGI2) receptor (IP receptor) agonist that is titrated to the highest tolerated or maximum dose of $1600 \mu \mathrm{g}$ BID (7). It is characterized by rapid absorption (maximum plasma concentration within $1-3 \mathrm{~h}$ ), bioavailability of $50 \%$ and a terminal halflife of $0.8-2.5 \mathrm{~h}$, which is extended by its active metabolite to $6.2-13.5 \mathrm{~h}(5)$. Treprostinil is a tricyclic benzidine prostacyclin analog with a half-life of $2-4 \mathrm{~h}$ in plasma, and is $100 \%$ bioavailable with rapid absorption following SC administration, which is similar to that of the intravenous route (6). Since both selexipag and treprostinil target the prostacyclin pathways, they share common side effects of headache, flushing, nausea or vomiting, jaw pain, diarrhea, myalgia and pain in the extremities. Infusion site pain is common when treprostinil is administered subcutaneously (8). Our patient had disease progression despite the triple combination of oral $\mathrm{PAH}$-specific medications, which led our decision to transition from selexipag to SC treprostinil. The patient was on the maximum dose of selexipag at $1600 \mu \mathrm{g}$ BID, while treprostinil 40 $\mathrm{ng} / \mathrm{kg} / \mathrm{min}$ has been reported to be an effective dose (9). We thus estimated a dose conversion of selexipag 200 $\mu \mathrm{g}$ BID equivalent to treprostinil $5 \mathrm{ng} / \mathrm{kg} / \mathrm{min}$. Based on the observations of the GRIPHON study, the temporary interruption of selexipag treatment is well tolerated and manageable (10), and the rapid absorption in SC administration of treprostinil may prevent clinical worsening during withdrawal from selexipag. Our protocol involved the reduction of the dose of selexipag by $200 \mu \mathrm{g} \mathrm{BID}$ and the simultaneous increase in the dose of treprostinil by 5 $\mathrm{ng} / \mathrm{kg} / \mathrm{min}$ daily, resulting in selexipag being weaned on the 8th day with treprostinil up titration to $40 \mathrm{ng} / \mathrm{kg} / \mathrm{min}$ (Table 1). During the transitional period, we reduced the dose of selexipag by $400 \mu \mathrm{g}$ rather than $200 \mu \mathrm{g}$ on day 3 upon the patient's complaint of flushing, fever, nausea and poor appetite. As a result, selexipag was weaned 1 day earlier than the schedule, while there was no change in the increase in daily treprostinil dose. The side effects of flushing and nausea gradually improved over the following days and her appetite returned on day 7 of the transition. She complained of infusion site pain on day 4, which peaked on day 5 and then gradually subsided, requiring an analgesic for 3 days (day 4 to 6) to control the pain. Her shortness of breath and chest tightness had reduced on day 7 with a treprostinil dose of 35 $\mathrm{ng} / \mathrm{kg} / \mathrm{min}$. This is in line with the decrease in BNP levels from $579 \mathrm{pg} / \mathrm{mL}$ before the transition to $320.3 \mathrm{pg} / \mathrm{mL}$ on day 7. Other evidence of clinical improvement, such as reduced estimated SPAP, LVel, and sizes of the right atrium and ventricle were noted on echocardiographic examination $(11,12)$. Improved right ventricular function was indicated by the increase of RVFAC and TAPSE. Furthermore, oxygen saturation measured by pulse oximeter increased during the transitional period. Considering all the above, there is no doubt that SC treprostinil was more effective than oral selexipag in the patient. The patient 
was discharged after completion of the transitional therapy on day 8 with a treprostinil dose of $40 \mathrm{ng} / \mathrm{kg} / \mathrm{min}$.

The routes of administration and the medications that work on the prostacyclin pathway may influence treatment efficacy. The successfully transition from parenteral to oral treprostinil in low-risk PAH patients has been reported (13), and patients with clinical deterioration can be safely and effectively transitioned from inhaled to parenteral treprostinil (14). The transition from inhaled treprostinil to oral treprostinil or selexipag, however, has been reported to lead to a clinical and hemodynamic deterioration in patients with PAH (15). The TRANSIT-1 study assessed the tolerability and safety of transitioning from inhaled treprostinil to oral selexipag in PAH. It was reported that three patients $(9 \%)$ discontinued the therapy due to adverse events or clinical worsening (16), leading an expert panel to recommend that patients with stable and low risk PAH with insufficient response or low tolerance to existing treprostinil therapy be considered candidates for transitions between oral and inhaled formulations (17). Currently, there are no standard guidelines for transitions from selexipag to SC treprostinil, and so the success of our approach to this transition may serve a useful guide in this regard. That said, close monitoring for clinical worsening, such as symptoms, progression of functional capacity, unstable vital signs linked to the withdrawal from the PAH-specific drug, and the development of side effects due to the administration of a new medication, is crucial.

\section{CONCLUSION}

The 8-day protocol presented here can serve as a guide in clinical practice for transitions from oral selexipag to SC treprostinil. The estimated equivalent dose of selexipag to treprostinil in our patient was $200 \mu \mathrm{g} \mathrm{BID}=5$ $\mathrm{ng} / \mathrm{kg} / \mathrm{min}$. Further investigations are needed to understand this transition.

\section{CONFLICTS OF INTEREST}

None declared.

\section{AUTHOR CONTRIBUTIONS}

Concept - W.J.H., C.P.L., L.A.H., C.L.W.; Planning and Design - W.J.H., C.P.L., L.A.H., C.L.W.; Supervision W.J.H., C.P.L., L.A.H., C.L.W.; Funding -; Materials C.P.L., L.A.H.; Data Collection and/or Processing W.J.H., C.P.L., L.A.H., C.L.W.; Analysis and/or Interpretation - W.J.H., C.P.L.; Literature Review - W.J.H., C.P.L.;
Writing - W.J.H., C.P.L.; Critical Review - W.J.H., C.P.L., L.A.H., C.L.W.

\section{YAZAR KATKILARI}

Fikir - W.J.H., C.P.L., L.A.H., C.L.W.; Tasarım ve Dizayn W.J.H., C.P.L., L.A.H., C.L.W.; Denetleme - W.J.H., C.P.L., L.A.H., C.L.W.; Kaynaklar -; Malzemeler - C.P.L., L.A.H.; Veri Toplama ve/veya Isşleme - W.J.H., C.P.L., L.A.H., C.L.W.; Analiz ve/veya Yorum - W.J.H., C.P.L.; Literatür Taraması - W.J.H., C.P.L.; Yazıyı Yazan - W.J.H., C.P.L.; Eleştirel İnceleme - W.J.H., C.P.L., L.A.H., C.L.W.

\section{REFERENCES}

1. Wang LY, Lee KT, Lin CP, Hsu LA, Wang CL, Hsu TS, ef al. Long-term survival of patients with pulmonary arterial hypertension at a single center in Taiwan. Acta Cardiol $\operatorname{Sin} 2017 ; 33: 498-509$. [CrossRef]

2. Huang WC, Hsu CH, Sung SH, Ho WJ, Chu CY, Chang $\mathrm{CP}$, et al. 2018 TSOC guideline focused update on diagnosis and treatment of pulmonary arterial hypertension. J Formos Med Assoc 2019; 1 18:1584-609. [CrossRef]

3. Galiè N, Humbert M, Vachiery JL, Gibbs S, Lang I, Torbicki A, et al. 2015 ESC/ERS Guidelines for the diagnosis and treatment of pulmonary hypertension: the Joint Task Force for the Diagnosis and Treatment of Pulmonary Hypertension of the European Society of Cardiology (ESC) and the European Respiratory Society (ERS); endorsed by: Association for European Paediatric and Congenital Cardiology (AEPC), International Society for Heart and Lung Transplantation (ISHLT). Eur Heart J 2016; 37:67119. [CrossRef]

4. Hoeper MM, Kramer T, Pan Z, Eichstaedt CA, Spiesshoefer J, Benjamin N, et al. Mortality in pulmonary arterial hypertension: prediction by the 2015 European pulmonary hypertension guidelines risk stratification model. Eur Respir J 2017; 50:1700740. [CrossRef]

5. Kaufmann P, Hurst N, Astruc B, Dingemanse J. Absolute oral bioavailability of selexipag, a novel oral prostacyclin IP receptor agonist. Eur J Clin Pharmacol 2017; 73:1516. [CrossRef]

6. Kumar P, Thudium E, Laliberte K, Zaccardelli D, Nelsen A. A comprehensive review of treprostinil pharmacokinetics via four routes of administration. Clin Pharmacokinet 2016; 55:1495-505. [CrossRef]

7. Sitbon O, Channick R, Chin KM, Frey A, Gaine S, Galiè $N$, et al. Selexipag for the treatment of pulmonary arterial hypertension. N Engl J Med 2015; 373:2522-33. [CrossRef] 
8. Barst RJ, Galiè N, Naeije R, Simonneau G, Jeffs R, Arneson $C$, et al. Long-term outcome in pulmonary arterial hypertension patients treated with subcutaneous treprostinil. Eur Respir J 2006; 28:1 195-203. [CrossRef]

9. Sadushi-Kolici R, Skoro-Sajer N, Zimmer D, Bonderman $D$, Schemper M, Klepetko W. et al. Long-term treatment, tolerability, and survival with subcutaneous treprostinil for severe pulmonary hypertension. J Heart Lung Transp 2012; 31:735-43. [CrossRef]

10. Preston IR, Channick RN, Chin K, Di Scala L, Farber HW, Gaine $S$, et al. Temporary treatment interruptions with oral selexipag in pulmonary arterial hypertension: insights from the prostacyclin (PGI2) receptor agonist in pulmonary arterial hypertension (GRIPHON) study. J Heart Lung Transplant 2018; 37:401-8. [CrossRef]

11. Ho WJ, Lin CP, Wang CL, Hsu LA, Yu KH, Luo SF, et al. Improvement of right ventricular function in pulmonary arterial hypertension with disease-specific therapy-a clinical observational study. Acta Cardiol Sin 2014; 30:236-44.

12. Rudski LG, Lai WW, Afilalo J, Hua L, Handshumacher MD, Chandrasekaran K, et al. Guidelines for the echocardiographic assessment of the right heart in adults: a report from the American Society of Echocardiography. J Am Soc Echocardiogr 2010; 23:685-13. [CrossRef]
13. Chakinala MM, Feldman JP, Rischard F, Mathier M, Broderick $M$, Leedom $N$, et al. Transition from parenteral to oral treprostinil in pulmonary arterial hypertension. J Heart Lung Transplant 2017; 36:193-201. [CrossRef]

14. Preston IR, Feldman J, White J, Franco V, Ishizawar D, Burger $C$, et al. Safety and efficacy of transition from inhaled treprostinil to parenteral treprostinil in selected patients with pulmonary arterial hypertension. Pulm Circ 2014; 4:456-61. [CrossRef]

15. AbuHalimeh BJ, Parambil JG, Tonelli AR. Different efficacy of inhaled and oral medications in pulmonary hypertension. Heart Lung 2017; 46:334-7. [CrossRef]

16. Frost $A$, Janmohamed M, Fritz JS, McConnell JW, Poch D Fortin TA, et al. Safety and tolerability of transition from inhaled treprostinil to oral selexipag in pulmonary arterial hypertension: results from the TRANSIT-1 study. J Heart Lung Transplant 2019; 38:43-50. [CrossRef]

17. Rahaghi FF, Allen RP, Balasubramanian VP, Chakinala MM, Elwing JM, Feldman J, et al. An expert panel Delphi consensus statement on patient selection and management for transitioning between oral and inhaled treprostinil. Pulm Pharmacol Ther 2021; 66:101979. [CrossRef] 